\title{
MODULATORS AND MILIEU IN PRERETINAL NEOVASCULARISATION
}

\author{
MIKE BOULTON, BHARTI PATEL, ASUD KHALIQ, PATRICK MORIARTY, JOHN JARVIS-EVANS, \\ DAVID MCLEOD \\ Manchester
}

It has long been established that preretinal neovascularisation follows retinal capillary non-perfusion and inner retinal ischaemia, ${ }^{1,2}$ but the precise mechanism whereby ischaemia stimulates new vessel growth is unclear. Some consider that hypoxia is the sole aetiological factor in preretinal neovascularisation (independent of growth modulators). ${ }^{3,4}$ Others advocate that vasoproliferation is mediated by the release of diffusible biochemical factors from the ischaemic area which induce new vessels to grow from adjacent capillaries and venules. ${ }^{1,5}$ The four major events of preretinal neovascularisation (i.e. basement membrane breakdown, endothelial cell migration, endotheliả cell proliferation and vessel remodelling) can be modulated by a variety of such soluble factors. ${ }^{6,7}$ These modulators, usually peptides, are growth-regulating molecules which have a wide spectrum of biological activities and which exert their actions by binding with specific receptor sites localised in the plasma membrane of target cells. ${ }^{8,9}$ Although the majority of these modulators are designated 'growth factors' this is probably a misleading term since they not only modulate cell proliferation but also regulate cell migration, extracellular matrix turnover, the production of adhesion molecules and a variety of other intrinsic biological activities.

The aim of this article is to consider the evidence supporting a crucial role for oxygen in retinal new vessel formation. From an in vivo perspective we will consider oxygen profiles in the normal retina and how they change under pathological conditions. From an in vitro perspective we will discuss why we believe routine cell culture studies are normally carried out under extremely hyperoxic, non-physiological conditions and how the intrinsic biological activity of retinal microvascular cells changes dramatically when cells are cultured within a more pertinent oxygen environment. Finally, we will consider the ori-

From: Departments of Ophthalmology and Cell and Structural Biology, University of Manchester, Oxford Road, Manchester, UK.

Correspondence to: Dr. Mike Boulton, Department of Ophthalmology, Manchester Royal Eye Hospital, Oxford Road, Manchester M13 9WH, UK. gin of ocular growth factors and attempt to reconcile otherwise conflicting hypotheses regarding the pathophysiology of preretinal neovascularisation.

\section{OXYGEN LEVELS IN THE NORMAL RETINA}

The retinal oxygen supply is derived from two sources: the choriocapillaris and the inner retinal capillary net. ${ }^{10}$ The choroidal circulation supplies oxygen to the avascular outer retina located between the choriocapillaris and the deep retinal capillaries (primarily the retinal pigment epithelium (RPE), photoreceptors and some neurons in deeper retinal layers). It is estimated that the choriocapillaris normally supplies $60 \%$ of the tissue in this avascular area while the other $40 \%$ is supplied by the inner retinal capillaries. $^{10,11}$

Standard textbooks of physiology quote the arterial $\mathrm{PO}_{2}$ as $100 \mathrm{mmHg}$, venous $P \mathrm{O}_{2}$ as $40 \mathrm{mmHg}$ and the $P \mathrm{O}_{2}$ in tissues generally as $35 \mathrm{mmHg}$. In the retina, the oxygen environment has been determined using micro-electrodes, and studies in animals have demonstrated a non-uniform distribution of oxygen supply and consumption in the various retinal layers. Oxygen tensions are highest in the region of the RPE/photoreceptor complex (up to 70$90 \mathrm{mmHg}$ ) while $\mathrm{PO}_{2}$ values can decrease to as low as $17 \mathrm{mmHg}$ in mid-retina. ${ }^{12-15}$ Values at the retina-vitreous interface appear to be intermediate between the two. There is also some topographic variation within the retina and immediately preretinally, $P_{2}$ values being slightly higher adjacent to arterioles than in intervascular areas. Since the values for transretinal oxygen tensions are similar in rabbits, cats, pigs and monkeys it is reasonable to assume that like $\mathrm{PO}_{2}$ levels are present in the human eye. Intravitreal oxygen tensions in man and rabbit are similar, $P_{2}$ values ranging from 14 to $20 \mathrm{mmHg}{ }^{15}$

\section{OXY GEN LEVELS IN THE PATHOLOGICAL RETINA}

Little is known about changes in retinal oxygen tension 
before and during preretinal neovascularisation, i.e. in the context of persisting retinal capillary non-perfusion. However, Maeda et al.$^{16}$ measured oxygen tensions during diabetic vitrectomy and recorded values of $12.1 \mathrm{mmHg}$ in the mid-vitreous cavity, $31.4 \mathrm{mmHg}$ above neovascular membranes, $14.8 \mathrm{mmHg}$ above the macula and $24.0 \mathrm{mmHg}$ in the subretinal space. The high value above the neovascular tissue probably reflects oxygen delivery without associated consumption. Stefansson et al. ${ }^{17}$ reported preretinal oxygen tensions of $110( \pm 42) \mathrm{mmHg}$ in patients undergoing vitrectomy for proliferative diabetic retinopathy (PDR). The difference in $\mathrm{PO}_{2}$ levels between the two studies may reflect differences in the oxygen breathing mixtures used; the patients of Maeda et al. were breathing normal air ( $21 \%$ oxygen) while those in Stefansson's study were breathing about $30 \%$ oxygen. ${ }^{17}$

In animals, experimental occlusion of the retinal blood vessels leads to a reduction in intraretinal oxygen tension and Wolbarsht et al.$^{18}$ reported a drop in preretinal oxygen tension from $20 \mathrm{mmHg}$ to zero after occlusion of the retinal circulation at the optic disc of the cat. Occlusion of retinal blood vessels in the pig leads to the development of local anoxia following arteriolar occlusion ${ }^{19,20}$ or local hypoxia following the occlusion of a venule. ${ }^{21}$ Stefansson et al. ${ }^{4}$ observed that temporary occlusion of the retinal circulation in albino rats resulted in a proliferative response with mitotic figures in both the retinal capillary endothelial cells and the pericytes, thus intimating a relationship between retinal oxygenation and cell proliferation in vivo.

\section{SCATTER PHOTOCOAGULATION}

Scatter photocoagulation is a proven treatment for preretinal neovascularisation. ${ }^{22}$ The mechanism by which retinal photocoagulation results in new vessel regression is unclear but a number of theories have been put forward: (1) destruction of the ischaemic retina curtails the production of angiogenic factors, ${ }^{23}$ (2) destruction of retinal tissue makes more oxygen available for the hypoxic inner retina ${ }^{24}$ and (3) cellular changes after photocoagulation stimulate production of an inhibitory modulator which induces regression of new vessels. ${ }^{25,26}$ Several experimental studies have shown that scatter photocoagulation increases retinal oxygen tension and may thus counteract retinal hypoxia. ${ }^{27-31}$ Furthermore, Stefansson and colleagues ${ }^{17}$ have recently shown that in patients undergoing vitreous surgery for PDR, the oxygen tension was significantly higher over areas of retina that had been treated with laser $(140 \pm 59 \mathrm{mmHg})$ than it was over untreated areas $(110 \pm 42 \mathrm{mmHg})$.

\section{CONSTRAINTS IN EXPERIMENTAL STUDIES}

In the absence of a practical animal model with which to study preretinal neovascularisation, research into the cellular mechanisms of new vessel formation has relied on either in vivo new vessel formation in non-retinal vascular beds or the use of in vitro culture techniques. ${ }^{6}$ Although valuable information on the identity and actions of growth stimulators and inhibitors has been obtained, these studies have largely ignored the role of oxygen in modulating their production and their interactions at the cellular level. The best tool for such studies is cell culture, which allows the effect of oxygen levels on retinal microvascular cell behaviour to be investigated.

\section{OXYGEN LEVELS IN CELL CULTURE MEDIA}

Cultured cells are routinely grown in an environment of $95 \%$ air $/ 5 \% \mathrm{CO}_{2}{ }^{32}$ This air $/ \mathrm{CO}_{2}$ mixture is misleadingly termed 'normoxia' while lower atmospheric oxygen concentrations are regarded as 'hypoxia'. However, measurements of oxygen tensions in growth medium exposed to 'normoxia' (i.e. $95 \%$ air $/ 5 \% \mathrm{CO}_{2}$ ) show a media $\mathrm{PO}_{2}$ of between 133 and $152 \mathrm{mmHg},{ }^{33-37}$ which is far higher than the highest oxygen tensions recorded in the normal adult retina $(70-90 \mathrm{mmHg}) .{ }^{12-15}$ Thus existing cell culture studies of the physiology of retinal microvascular cells have failed both to mimic the in vivo situation and to address the role of hypoxia in cellular function. A further problem is that of the few publications that are available, most have failed to measure the $\mathrm{PO}_{2}$ levels in the media and claims of achieving hypoxia in vitro may well be unfounded.

\section{EFFECT OF OXYGEN ON IN VITRO CELL PROLIFERATION}

Rosen et $\mathrm{al}^{36}$ demonstrated that the proliferation of retinal microvascular cells in vitro is dependent on oxygen concentration. The proliferation of retinal microvascular endothelial cells, retinal pericytes and Tenon's fibroblasts was greatest at a media $P \mathrm{O}_{2}$ of $82 \mathrm{mmHg}$ and decreased as the media $\mathrm{PO}_{2}$ increased. The decrease in the proliferative ability of cells exposed to higher oxygen concentrations could be reversed if the cells were returned to lower oxygen environments. In addition, it was observed that endothelial cells were more sensitive to changes in the oxygen environment than were either pericytes or fibroblasts. An extension of this study has examined cell proliferation of these cell types at a media $P_{2}$ of less than $82 \mathrm{mmHg}$ (Boulton et al. unpublished). Cells exposed to a $\mathrm{PO}_{2}$ of $30-50 \mathrm{mmHg}$ exhibited similar growth characteristics to those exposed to a $\mathrm{PO}_{2}$ of $82 \mathrm{mmHg}$ while $14-17 \mathrm{mmHg}$ resulted in a proliferative capacity lower than at either 82 or $133 \mathrm{mmHg}$; no cell cytotoxicity was observed. A typical example is shown for Tenon's fibroblasts in Fig. 1a. The response of these cells to low oxygen appears to be a general phenomenon since a similar result has been reported for a variety of non-ocular cell types. ${ }^{33-35.38}$ Whether oxygen acts directly or indirectly to modulate cell behaviour is unclear. However, the studies described below support an indirect mechanism through which oxygen can modulate cells via the production of, and response to, growth factors.

\section{THE EFFECT OF OXYGEN ON THE PRODUCTION OF GROWTH MODULATORS}

Despite the hypothesis by Michaelson ${ }^{5}$ that retinal hypo- 

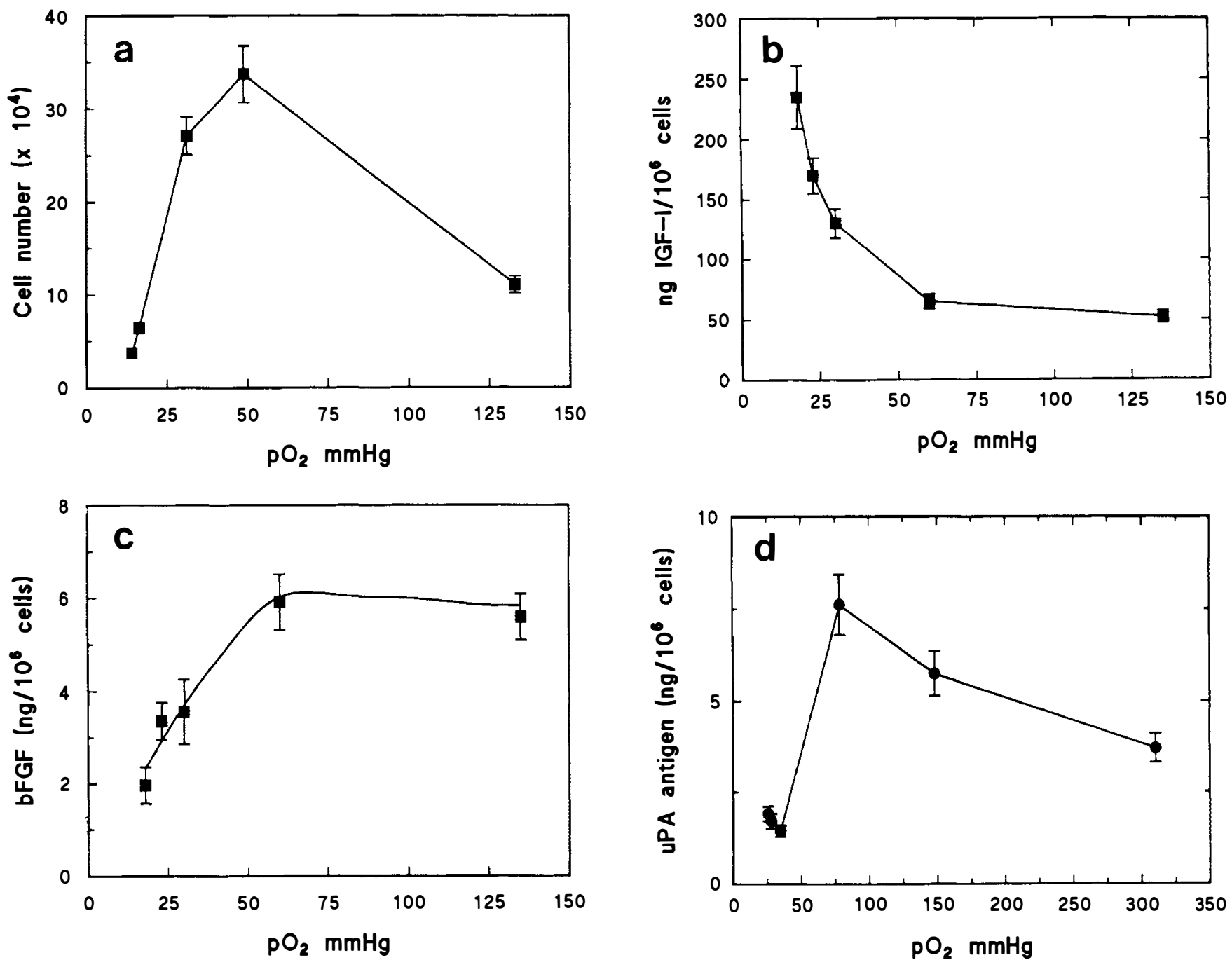

Fig. 1. Graphs showing the effect of oxygen on in vitro cell behaviour. (a) Comparison of the proliferative capacity of Tenon's capsule fibroblasts exposed to varying oxygen concentrations. Cell counts were performed 3 days post plating. (b) Levels of IGF-I in serum-free conditioned media from confluent cultures of pericytes exposed to varying oxygen concentrations for 48 hours. IGF-I levels were determined by radioimmunoassay. (c) Intracellular bFGF levels in confluent cultures of pericytes exposed to varying oxygen concentrations for 48 hours. Cell lysates were prepared by exposing monolayers to Triton $\mathrm{X}-100 / \mathrm{NH}_{4} \mathrm{OH}$ and bFGF levels were determined by radioimmunoassay. (d) Levels of uPA in plasma-containing conditioned media (Dulbecco's modified Eagle's medium $+7.5 \%$ human platelet-poor plasma) from confluent cultures of RPE cells exposed to varying oxygen concentrations for 48 hours. uPA levels were determined by an ELISA kit (Biopool, Sweden). Vertical bars indicate SEM ( $\mathrm{n}>6)$.

xia results in the production of diffusible biochemical factors which mediate new vessel growth, and the subsequent identification and characterisation of a plethora of such factors, ${ }^{6-9}$ the effect of hypoxia per se on the production of such growth modulators has received little attention.

By way of background, in non-ocular tissues the levels of platelet-derived growth factor (PDGF) in the culture media overlying pulmonary and aortic endothelial cells have been shown to increase under hypoxia as compared with normoxia. ${ }^{39} \mathrm{~A}$ similar response was seen in the production of cytokine neutrophil attractant activity by pulmonary endothelial cells. ${ }^{40}$ Conversely exposure of aortic and microvascular endothelial cells to hypoxia (14 $\mathrm{mmHg}$ ) resulted in decreased levels of endogenous basic fibroblast growth factor (bFGF) when compared with cells grown in 'normoxia' $(145 \mathrm{mmHg}) .{ }^{35}$ The production of tissue plasminogen activator (tPA) and its inhibitor PAI-1 (factors which modulate extracellular matrix turnover) were also influenced by the oxygen tension in the media. $^{41,42}$

Recent studies in this laboratory have begun to elucidate the effect of oxygen on the production of growth modulators by retinal cells. We have shown that cultured retinal microvascular endothelial cells, pericytes and RPE cells release insulin-like growth factor-I (IGF-I), which is a potent mitogenic and metabolic modulator of many cell types ${ }^{43}$ and that production increases towards hypoxia (Fig. 1b). Furthermore, the response to IGF-I in many tissues is modulated by high-affinity IGF binding proteins (IGFBPs) of which several forms exist. A whole host of cell types have been shown to produce IGFBPs, and these binding proteins can either inhibit or enhance local IGF-I action. ${ }^{43}$ Pilot studies using western ligand blot analysis have demonstrated cell-specific differences in the types of 
IGFBP synthesised by retinal microvascular endothelial cells, retinal pericytes, RPE and Tenon's fibroblasts cells. With the exception of endothelial cells production of IGFBPs is sensitive to oxygen concentration. The production of some IGFBPs is 5- to 8-fold greater at a $\mathrm{PO}_{2}$ of 18 $\mathrm{mmHg}$ than at $150 \mathrm{mmHg}$ and the reverse profile is evident for other IGFBP isoforms.

Parallel studies on the effect of oxygen on bFGF (a potent endothelial cell mitogen ${ }^{8}$ ) have shown that endogenous levels of this growth factor decrease as the $\mathrm{PO}_{2}$ levels are reduced from 75 to $18 \mathrm{mmHg}$ (Fig. 1c). These results are similar to those reported by Shreeniwas et al. ${ }^{35}$ Initial studies indicate a similar profile for transforming growth factor-beta (TGF- $\beta$ ), with secreted levels decreasing from normoxia to hypoxia.

Finally, studies on RPE cells suggest that oxygen may modulate the production of plasminogen activators and their inhibitors by microvascular cells. ${ }^{44}$ Production of urokinase plasminogen activator (UPA) by RPE cells was greatest at a $\mathrm{PO}_{2}$ level of approximately $75 \mathrm{mmHg}$ but uPA secretion decreased if the $\mathrm{PO}_{2}$ levels were increased or reduced (Fig. 1d). In contrast PAI-1 production was lowest at a $\mathrm{PO}_{2}$ of $35 \mathrm{mmHg}$ and increased at lower or higher oxygen tensions.

\section{EFFECT OF OXYGEN ON IN VITRO RESPONSES TO GROWTH MODULATORS}

In the only study to date on the effect of oxygen on the

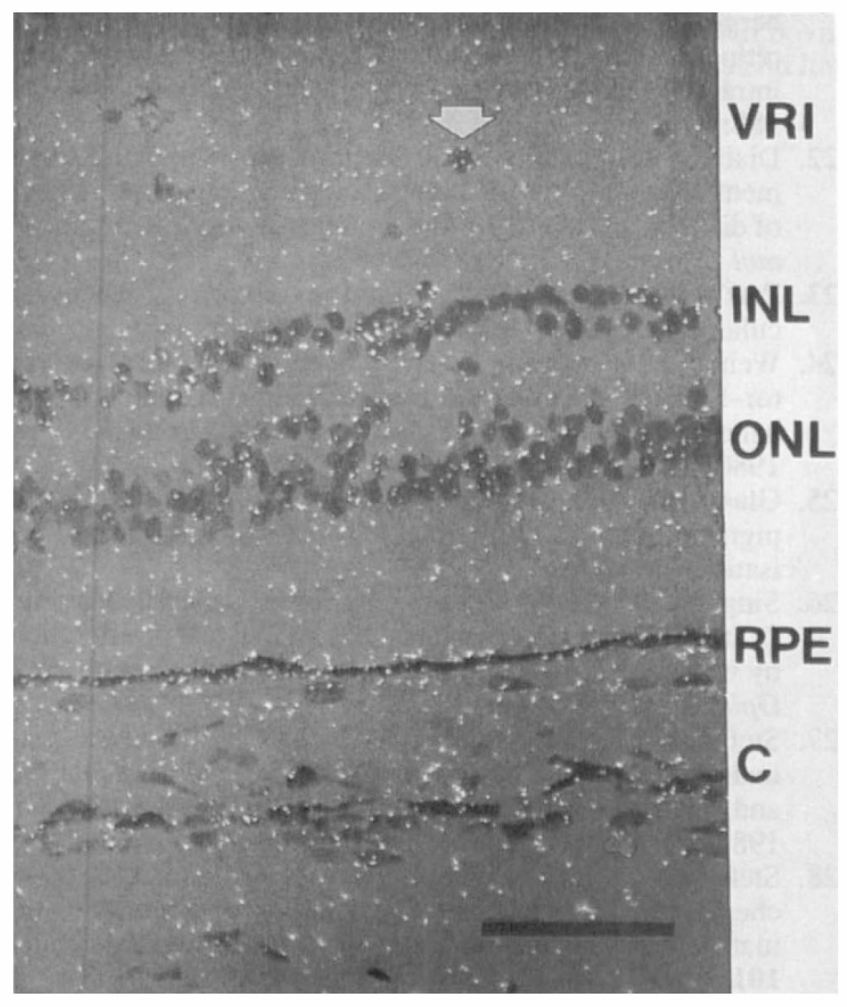

Fig. 2. Expression of IGF-I mRNA in a section of normal human retina viewed by epi-polarisation microscopy. Low-level labelling can be seen in the inner and outer nuclear layers (INL and ONL respectively), retinal pigment epithelium (RPE), choroid $(C)$ and occasional ganglion cells (arrow). VRI denotes the vitreous-retina interface. Scale bar represents $50 \mu \mathrm{m}$. response of endothelial cells to growth modulators, Shreeniwas et al. ${ }^{35}$ observed that exposure of cultured aortic or adrenal cortex capillary endothelial cells immediately after subculturing led to a dose-dependent decrease in cell growth once $\mathrm{PO}_{2}$ values below $47 \mathrm{mmHg}$ were reached. However, when exogenous bFGF was added to the hypoxic cultures $\left(\mathrm{PO}_{2}=14 \mathrm{mmHg}\right)$, growth was stimulated in a dose-dependent manner with a maximal 12 -fold increase above growth in unstimulated hypoxic controls. A similar response was observed with aortic endothelial cells but the level of stimulation was not as great. Furthermore, receptor binding studies demonstrated a $300 \%$ increase in highaffinity bFGF receptors in hypoxic cultures as compared with those exposed to $147 \mathrm{mmHg} P_{2}$. Thus $P_{2}$ can affect the response to growth modulators (probably via receptor up-regulation) as well as growth modulator production.

\section{SOURCE OF GROWTH MODULATORS IN THE EYE}

Although there is considerable evidence implicating a role for growth modulators in normal retinal homeostasis and in proliferative disorders of the vitreous, there is little evidence to indicate whether these molecules are transcribed locally or are of systemic origin. In situ hybridisation studies in this laboratory have confirmed the transcription of one such modulator, IGF-I, in the normal human retina. Low levels of expression were observed in the inner and outer nuclear layers, the RPE and choroid (Fig. 2). In addition, expression could also be observed in some ganglion cells and cone photoreceptor cells. The autocrine/ paracrine role of this factor in retinal homeostasis is at present unclear.

With respect to growth modulator production in proliferative disorders of the vitreous, mRNA expression of IGF-I, IGF-II, TGF- $\beta$ and epithelial growth factor (EGF) can all be observed in epiretinal membranes excised during vitrectomy. The message can either be generalised throughout the membrane or specifically located in certain

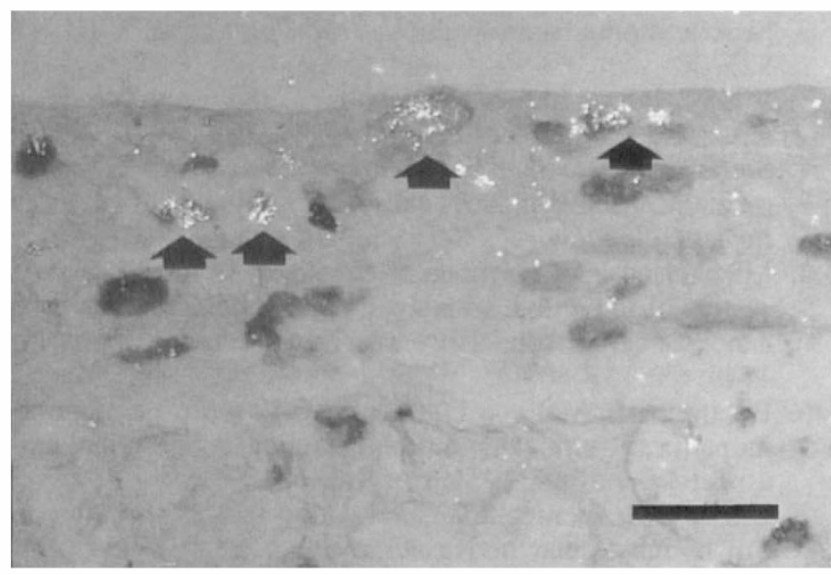

Fig. 3. Expression of IGF-I mRNA in a section of a late-stage $P D R$ epiretinal membrane viewed by epi-polarisation microscopy. Heavy labelling can be seen associated with some cells towards the edge of the membrane (arrows). Scale bar represents $30 \mu \mathrm{m}$. 
cells within the tissue (Fig. 3). In all cases mRNA expression in the membranes was higher than that seen in the normal retina. Although the full implications of these results have yet to be appreciated they do suggest that autocrine/paracrine mechanisms may be a significant component in proliferative disorders in the vitreous.

\section{CONCLUSIONS}

It is becoming increasingly evident that retinal and retinal vascular homeostasis are dependent on a fine balance between growth stimulators and inhibitors. Immunohistochemistry and/or in situ hybridisation studies clearly demonstrate that aFGF, bFGF, IGF-I, TGF- $\beta$, tPA and uPA are all expressed in the normal retina ${ }^{45-48}$ and that the levels of these modulators are often dramatically increased during retinal pathologies. ${ }^{49-52}$ In vitro studies from this and other laboratories suggest that the production of, and response to, such growth modulators is influenced by the local oxygen environment. The variability of this responsiveness (i.e. some increase towards hypoxia, some decrease towards hypoxia, while others exhibit an intermediate profile) suggests that several growth modulators may have an individual role in the ultimate neovascular response. Furthermore, the identification of mRNA expression for these growth factors in the normal retina and in epiretinal membranes suggests an autocrine/paracrine action. Further investigations are underway in an attempt to elucidate the interplay between growth modulators and oxygen, and its importance in the cascade of events leading to preretinal neovascularisation.

These studies were supported by the Wellcome Trust, Manchester Royal Eye Hospital Ophthalmic Research Endowments and the North Western Regional Health Authority. The authors are indebted to Joanne Mather and Alison Stansfield for their technical assistance.

\section{REFERENCES}

1. Ashton N: Arteriolar involvement in diabetic retinopathy. Br J Ophthalmol 1953, 37: 282-92.

2. Ashton N: Studies of retinal capillaries in relation to diabetic and other retinopathies. Br J Ophthalmol 1963, 47: 521-38.

3. Wise GN: Retinal neovascularisation. Trans Am J Ophthalmol Soc 1956, 54: 729-826.

4. Stefansson E, Wilson CA, Schoen T, Kuwabara T: Experimental ischaemia induces cell mitosis in the adult rat retina. Invest Ophthalmol Vis Sci 1988, 29: 1050-5.

5. Michaelson IC: The mode of development of the vascular system of the retina, with some observations on its significance for certain retinal diseases. Trans Ophthalmol Soc UK 1948, 68: 137-86.

6. Boulton ME, McLeod D, Garner A: Vasoproliferative retinopathies: clinical, morphogenetic and modulatory aspects. Eye 1988, 2 (Suppl): S124-S139.

7. Glaser BM: Extracellular modulating factors and the control of intraocular neovascularisation: an overview. Arch Ophthalmol 1988, 106: 603-7.

8. Klagsbrun N and D'Amore P: Regulators of angiogenesis. Ann Rev Physiol 1991, 53: 217-39.

9. Schultz GS and D'Amore P: Neovascular growth factors. Eye 1991, 5: 170-80.

10. Dollery CT, Bulpitt CJ, Kohner EM: Oxygen supply to the retina and choroidal circulations at normal and increased arterial oxygen tensions. Invest Ophthalmol Vis Sci 1969, 8: 588-94.

11. Tornquist $P, A l m$ A: Retinal and choroidal contribution to retinal metabolism in vivo: a study in pigs. Acta Physiol Scand 1979, 106: 315-57.

12. Alder VA, Cringle SJ, Constable IJ: The retinal oxygen profile in cats. Invest Ophthalmol Vis Sci 1983, 24: 30-6.

13. Diddie KR, Ernest JT: the effect of photocoagulation on the choroidal vasculature and retinal oxygen tension. Am J Ophthalmol 1977, 84: 62-6.

14. Pouranaras CJ, Riva CE, Tsacopoulos M, Strommer K: Diffusion of $\mathrm{O}_{2}$ in the retina of anesthetized miniature pigs in normoxia and hyperoxia. Exp Eye Res 1989, 49: 347-60.

15. Sakaue H, Negi A, Honda Y: Comparative study of vitreous oxygen tension in human and rabbit eyes. Invest Ophthalmol Vis Sci 1989, 88: 1933-7.

16. Maeda N, Tano Y, Ikeda T, Imai T, Hamano H, Manabe R: Oxygen tension in the vitreous cavity of a diabetic patient. Invest Ophthalmol Vis Sci 1990, 31 (Suppl): 124.

17. Stefansson E, Machemer R, de Juan E, McCuen BW, Peterson J: Retinal oxygenation and laser treatment in patients with diabetic retinopathy. Am J Ophthalmol 1992, 113: 36-8.

18. Wolbarsht ML, Stefansson E, Landers MB: Retinal oxygenation from the choroid in hyperoxia. Exp Biol 1987, 47: 49-52.

19. Tsacopoulos M, Baker R, Levy S: Studies on retinal oxygenation. Adv Exp Med Biol 1976, 75: 413-6.

20. Pouranaras CJ, Ilic J, Gilodi N: Physiopathologie de la circulation rétinienne: conséquences d'une occlusion vasculature rétinienne aiguë. Klin Monatsbl Augenheilkd 1985, 186: 471-6.

21. Pouranaras CJ, Ilic J, Gilodi N, Tsacopoulos M, Leuenberger PM: Occlusion veineuse expérimentale: le rôle de la rétine ischemique dans le développement des neovaisseaux intra- ou prerétiniens. Klin Monatsbl Augenheilkd 1986, 188: $345-7$.

22. Diabetic Retinopathy Study Group: Photocoagulative treatment of proliferative diabetic retinopathy: the second report of diabetic retinopathy study findings. Trans Acad Ophthalmol Otolaryngol 1978, 85: 82-92.

23. Patz A: Clinical and experimental studies on retinal neovascularisation. Am J Ophthalmol 1982, 94: 715-43.

24. Weiter JJ, Zuckerman R: The influence of the photoreceptor-RPE complex on the inner retina: an explanation for the beneficial effects of photocoagulation. Ophthalmology 1980, 87: 1133-9.

25. Glaser BM, Campochiaro PA, Davis JL, Jerdan JA: Retinal pigment epithelial cells release inhibitors of neovascularisation. Ophthalmology 1987, 94: 780-4.

26. Singh A, Boulton M, Lane C, Forrester J, Gaal J, McLeod D: Inhibition of microvascular endothelial cell proliferation by vitreous following retinal scatter photocoagulation. $\mathrm{Br} \mathrm{J}$ Ophthalmol 1990, 74: 328-32.

27. Stefannson E, Landers MB, Wolbarsht ML: Increased retinal oxygen supply following panretinal photocoagulation and vitrectomy and lensectomy. Trans Am Ophthalmol Soc 1981, 79: 307-34.

28. Stefansson E, Hatchell DL, Fisher BL, Sutherland FS, Maschemar R: Panretinal photocoagulation and retinal coagulation in normal and diabetic cats. Am J Ophthalmol 1986, 101: 657-64.

29. Molnar I, Poitry S, Tsacopoulos M, Giladi N, Leuenberger PM: Effect of laser photocoagulation on oxygenation of the retina in miniature pigs. Invest Ophthalmol Vis Sci 1985, 26: $1410-4$.

30. Alder VA, Cringle SJ, Brown M: The effect of regional retinal photocoagulation on vitreal oxygen tension. Invest Ophthalmol Vis Sci 1987, 28: 1078-87. 
31. Novack RL, Stefansson E, Hatchell DL: The effect of photocoagulation on the oxygenation and ultrastructure of avascular retina. Exp Eye Res 1990, 50: 289-301.

32. Freshney RI: Culture of Animal Cells: A Manual of Basic Techniques. New York: Alan R. Liss, 1987.

33. Balin AK, Goodman D, Rasmussen H, Cristofalo VJ: The effect of oxygen tensions on the growth and metabolism of WI-38 cells. J Cell Physiol 1976, 89: 235-50.

34. Taylor GW, Camalier RF, Sanford KK: Density dependent effects of oxygen on the growth of mammalian fibroblasts in culture. J Cell Physiol 1978, 95: 33-40.

35. Shreeniwas R, Ogawa S, Cozzolino F, Torcia G, Braunstein $\mathrm{N}$, Butura C, et al.: Macrovascular and microvascular endothelium during long term hypoxia: alterations in cell growth, monolayer permeability, and cell surface coagulant properties. J Cell Physiol 1991, 146: 8-17.

36. Rosen P, Boulton ME, Moriaty P, Khaliq A, McLeod D: Effect of varying oxygen concentrations on the proliferation of retinal microvascular cells in vitro. Exp Eye Res 1991, 53: $597-601$.

37. Moriarty P, Khaliq A, Boulton ME, McLeod D: The role of hypoxia in diabetic retinopathy. In: Rifkin $\mathrm{H}$, Colwell $\mathrm{J}$, Taylor S, eds. Diabetes: International Proceedings of the International Diabetic Federation, Washington. Amsterdam: Elsevier, 1991: 458-61.

38. Storch TG, Talley GD: Oxygen concentration regulates the proliferative response of human fibroblasts to serum and growth factors. Exp Cell Res 1988, 175: 317-25.

39. Bounelis P, Magargal W, King S, Booyse F, Oparil S, Miller D: Hypoxia stimulates platelet derived growth factor gene expression by pulmonary artery endothelial cells. Clin Res 36: 503A.

40. Farber HW and Rounds S: Effect of long term hypoxia on cultured aortic and pulmonary arterial endothelial cells. Exp Cell Res 1990, 191: 27-36.

41. Wojta J, Jones RL, Binder BR, Hoover RL: Reduction in $\mathrm{PO}_{2}$ decreases the fibrinolytic potential of cultured bovine endothelial cells derived from pulmonary arteries and lung microvasculature. Blood 1988, 71: 1703-6.
42. Shatos MA, Doherty JM, Stump DC, Thompson EA, Collen $\mathrm{D}$ : Oxygen radicals generated during anoxia followed by reoxygenation reduce the synthesis of tissue-type plasminogen activator and plasminogen activator inhibitor-1 in human endothelial cell culture. I Biol Chem 1990, 265: 20444-8.

43. LeRoith D and Raizada MK: Molecular Biology of InsulinLike Growth Factors and their Receptors. New York: Plenum Press, 1989.

44. Boulton M, Jarvis-Evans J, Khaliq A, McLeod D: uPA and PAI production by cultured human RPE cells: modulation by $\mathrm{PO}_{2}$. Invest Ophthalmol Vis Sci 1992, 33 (Suppl): 910.

45. McAvoy JW and Chamberlain CG: Growth factors in the eye. Prog Growth Factor Res 1990, 2: 29-43.

46. Danias J and Stylianopoulou F: Expression of IGF-I and IGF-II genes in the adult rat eye. Curr Eye Res 1990, 9: 379-86.

47. Hanneken A, de Juan E, Lutty GA, Fox GM, Schiffer S, Hjelmeland LM: Altered distribution of basic fibroblast growth factor in diabetic retinopathy. Arch Ophthalmol 1991, 109: 1005-11.

48. Lutty GA, Merges C, Threlkeld A, Crone S, McLeod D: Heterogeneity in localisation of different forms of TGF- $\beta$ in human retina, vitreous and choroid. Invest Ophthalmol Vis Sci 1992, 33 (Suppl): 1028.

49. Baird A, Coller F, Jones K, Guillemin R: Angiogenic factor in human ocular fluid. Lancet 1985, ii: 563.

50. Grant M, Russel B, Fitzerald C, Merimee TJ: Insulin-like growth factor in the vitreous. Diabetes 1986, 35: 53-64.

51. Connor TB, Roberts AB, Sporn MB, Danielpour D, Dart LL, Michels RG, et al.: Correlation of fibrosis and transforming growth factor- $\beta$ type 2 levels in the eye. J Clin Invest 1989, 83: 1661-6.

52. Sivalingham A, Kenney J, Brown GC, Benson WE, Donoso $\mathrm{L}$ : Basic fibroblast growth factor levels in the vitreous with proliferative diabetic retinopathy. Arch Ophthalmol 1990, 108: $869-72$. 